\title{
Otak dan Akal dalam Ayat-Ayat Neurosains
}

\author{
Fu`ad Arif Noor \\ Sekolah Tinggi Pendidikan Islam (STPI) \\ Bina Insan Mulia Yogyakarta \\ Gg. Jemb. Merah No.116, Kaliwaru, Condongcatur, Kec. Depok, \\ Kabupaten Sleman, Daerah Istimewa Yogyakarta 55281 \\ E-Mail; fuad.arif.noor@gmail.com
}

\begin{abstract}
Abstrak
Neurosains secara sederhana adalah ilmu yang khusus mempelajari Neoron (sel saraf). Sel-sel saraf ini menyusun system saraf, baik susunan saraf pusat (otak dan saraf tulang belakang) maupun saraf tepi (31 pasang saraf spinal dan 12 pasang saraf kepala). Sel saraf sendiri bukan unit terkecil lagi dari sel saraf, unit terkecil dari sel saraf (neuron) adalah sinapsis yaitu titik pertemuan 2 sel saraf yang memindahkan dan meneruskan informasi (neurotransmitter). Pada tingkat biologi molekuler, unit terkecilnya adalah seperti gen-gen (kajian genetika). Umumnya para neurosaintis memfokuskan pada sel saraf yang ada di otak. Dalam Al-Qur'an akal memiliki kedudukan yang mulia. Hal itu terbukti kata "akal" dalam AlQur'an disebutkan dalam jumlah yang banyak. Kata "akal" dalam AlQur'an disebut sebanyak 49 kali. Seluruhnya dalam bentuk fi'il muḍāri' (kata kerja yang menunjukkan saat ini dan masa yang akan datang), kecuali satu yang berbentuk fi'il māọī (kata kerja yang menunjukkan masa lampau). Meskipun Al-Qur'an tidak menyebutkan "akal" dalam bentuknya sebagai 'bagian tertentu dari diri manusia' (جوهرا مستقلا في النفس), yang menjadi sumber lahirnya segala perbuatan rasional, namun Al-Qur'an menyebutkan "akal" dalam maknanya sebagai 'aktivitas menggunakan akal' (عملية التعقل), yaitu seruan yang mengajak menggunakan akal sebagai jalan menuju kebenaran (لتعنل)), berpikir (التفك)), memerhatikan (النظر), memahami dan mempelajari (التفقه), mengambil hikmah dan pelajaran dari setiap kejadian (الاعتبار), dan semacamnya.
\end{abstract}

Kata Kunci : Otak, Akal dan ayat-ayat Neurosains. Abstract

Neuroscience is simply the science that specifically studies Neurons (nerve cells). These nerve cells make up the nervous system, both the central nervous system (brain and spinal cord) and peripheral nerves (31 pairs of spinal nerves and 12 pairs of head nerves). Nerve cells themselves are no longer the smallest unit of nerve cells, the smallest unit of nerve cells (neurons) in synapses, which are the meeting points of two nerve cells that move and forward information (neurotransmitters). At the level of molecular biology, the smallest units are like genes (genetic studies). Generally, neuroscientists focus on nerve cells in the brain. In the Qur'an, the mind has a noble position. It was proven that the word "reason" in the Qur'an is mentioned in large numbers. The word "reason" in the Qur'an is mentioned 49 times. All of them are in the form of 'muilāri' (a verb that indicates the 
present and the future), except for the one in the form of 'mādī (a verb denoting the past). Although the Qur'an does not mention "reason" in its form as "a certain part of humanity" (جو هرا مستقلا فى النفس), which is the source of birth for all rational actions, but the Qur'an refers to "reason" in its meaning as " activities using reason '(عملية التعقل)( i.e. calls to use reason as a

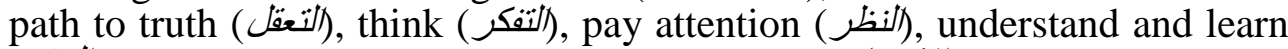
(التققه), take wisdom and lessons from each event (لاعبر), etc.

\section{Keywords: Brain, Intellect and Neurosciences verses.}

\section{A. Pendahuluan}

enelitian ilmiah dari sistem saraf telah meningkat secara signifikan pada
paruh kedua abad kedua puluh, terutama karena kemajuan dalam biologi
molekuler, elektrofisiologi, dan komputasi ilmu syaraf. Hal ini memungkinkan ahli saraf untuk mempelajari sistem saraf dalam segala aspeknya: bagaimana strukturnya, cara kerjanya, bagaimana berkembangnya, bagaimana malfungsi hal tersebut, dan bagaimana hal itu dapat diubah. Neuron adalah sel khusus untuk komunikasi. Mereka mampu berkomunikasi dengan neuron dan jenis sel lain melalui sambungan khusus yang disebut sinapsis, dimana sinyal listrik atau elektrokimia dapat ditransmisikan dari satu sel ke sel lainnya. Banyak neuron mengekstrusi filamen tipis panjang protoplasma yang disebut akson, yang dapat memperpanjang ke bagian tubuh yang jauh dan mampu membawa sinyal listrik dengan cepat, mempengaruhi aktivitas neuron lain, otot, atau kelenjar pada titik-titik terminasi mereka. Sebuah sistem saraf muncul dari kumpulan neuron yang saling terhubung satu sama lain.

Neurosains atau Ilmu syaraf adalah bidang ilmu yang mempelajari sistem saraf atau sistem neuron (Definition of NEUROSCIENCE, n.d.). Area studi mencakup struktur, fungsi, sejarah evolusi, perkembangan, genetika, biokimia, fisiologi, farmakologi, informatika, penghitungan neurosains dan patologi sistem saraf. Awalnya merupakan cabang dari ilmu biologi, namun ilmu ini telah berkembang dan menarik berbagai jenis ilmu lain untuk memanfaatkan pendekatan ilmu syaraf termasuk diantaranya adalah kognitif, neuro-psikologi, ilmu komputer, statistika, fisika dan kedokteran.

Rentang bidang ilmu syaraf telah meluas dengan mengikut sertakan percobaan ilmiah secara sistematis maupun penyelidikan teoritis dari sistem saraf pusat maupun sistem saraf tepi dari organisme biologis. Metodologi empiris yang digunakan oleh ilmuwan ilmu syaraf saat ini telah berkembang dengan cepat. Dari studi molekuler dan seluler dari sel-sel saraf individu hingga pemotretan sensor, dan dan tugas motorik di otak. 
Karena semakin berkembangnya jumlah ilmuwan yang mempelajari bidang studi ini, beberapa organisasi neuroscience terkemuka telah dibentuk untuk menyediakan forum untuk semua ahli saraf dan pendidik. Contohnya, International Brain Research Organization didirikan pada 1960, International Society for Neurochemistry pada tahun 1963 ("International Brain Research Organization," 2019), European Brain and Behaviour Society pada tahun 1968 ("European Brain and Behaviour Society," 2019), dan Society for Neuroscience pada tahun 1969 (Society for Neuroscience-About, n.d.).

Pada vertebrata, sistem saraf dapat dibagi menjadi dua bagian, sistem saraf pusat (otak dan sumsum tulang belakang), dan sistem saraf perifer. Dalam banyak spesies termasuk semua vertebrata, sistem saraf adalah sistem organ yang paling kompleks dalam tubuh, dengan sebagian besar kompleksitas yang berada di otak. Otak manusia sendiri mengandung sekitar seratus miliar neuron dan seratus triliun sinapsis; terdiri dari ribuan substruktur yang dibedakan, terhubung satu sama dengan yang lain dalam jaringan sinaptik yang kerumitan mulai terurai. Mayoritas dari sekitar 20-25,000 gen milik genom manusia dinyatakan secara khusus di dalam otak. Karena plastisitas otak manusia, struktur sinapsis dan fungsi mereka sehingga berubah sepanjang hidup (Mental Health: A Report of the Surgeon General, n.d., p. 38).

Dengan demikian tantangan membuat rasa semua kompleksitas ini berat, Studi tentang sistem saraf dapat dilakukan pada berbagai tingkat, mulai dari tingkat molekuler dan seluler dengan sistem dan tingkat kognitif. Pada tingkat molekuler, pertanyaan dasar dibahas dalam neuroscience molekuler termasuk mekanisme di mana neuron mengekspresikan dan merespon sinyal molekul dan bagaimana akson membentuk pola konektivitas kompleks. Pada tingkat ini, peralatan dari biologi molekuler dan genetika digunakan untuk memahami bagaimana neuron berkembang dan bagaimana perubahan genetik mempengaruhi fungsi biologis. Morfologi, identitas molekul, dan karakteristik fisiologis neuron dan bagaimana mereka berhubungan dengan berbagai jenis perilaku juga menarik untuk dikaji.

Pertanyaan-pertanyaan mendasar dibahas dalam ilmu saraf seluler termasuk mekanisme bagaimana neuron memproses sinyal fisiologis dan elektrokimia. Pertanyaan-pertanyaan ini mencakup bagaimana sinyal diproses oleh neurites - ekstensi tipis dari badan sel saraf, terdiri dari dendrit (mengkhususkan diri untuk menerima input sinaptik dari neuron lain) dan akson (mengkhususkan diri untuk melakukan impuls saraf yang disebut potensial aksi)- dan somas (badan sel neuron yang mengandung inti), dan bagaimana neurotransmitter dan sinyal listrik ini digunakan untuk memproses informasi dalam neuron. Area utama lain neuroscience diarahkan pada pemeriksaan dari perkembangan sistem saraf. Pertanyaan-pertanyaan ini meliputi pola dan regionalisasi 
dari sistem saraf, sel induk saraf, diferensiasi neuron dan glia, migrasi neuronal, aksonal dan pengembangan dendritik, interaksi trofik, dan pembentukan sinaps.

Pada tingkat sistem, pertanyaan yang dibahas dalam sistem ilmu saraf termasuk bagaimana sirkuit neural terbentuk dan digunakan anatomis dan fisiologis untuk menghasilkan fungsi seperti refleks, integrasi multiindrawi, koordinasi motorik, irama sirkadian, respon emosional, pembelajaran, dan memori. Dengan kata lain, mereka membahas bagaimana sirkuit saraf berfungsi dan melalui perilaku mekanisme yang dihasilkan. Bidang yang terkait neuroethologi dan neuropsikologi menjawab berbagai pertanyaan tentang bagaimana substrat saraf mendasari hewan tertentu dan perilaku manusia. Neuroendocrinology dan psikoneuroimunologi meneliti interaksi antara sistem saraf dan endokrin dan sistem kekebalan tubuh masing-masing. Meskipun banyak kemajuan, cara jaringan neuron menghasilkan kognisi kompleks dan perilaku masih kurang dipahami. Hal ini mengindikasikan bahwa ayat-ayat Al-Qur'an menjunjung tinggi akal dan segala makna yang terkandung di dalamnya, sehingga penulis menyajikan perihal yang secara khusus mengungkap fenomena otak dan akal, pengertian akal beserta kedudukannya dalam ayat-ayat Neurosains.

\section{B. Fenomena OtaK dan AKaL}

Sebelum sampai kepada pengertian konsep al-'aql secara utuh, dalam kehidupan atau percakapan sehari-hari terdapat suatu fenomena tentang otak dan akal ibarat dua sisi dari mata uang logam, sulit dipisahkan baik kata maupun makna, ada keterikatan dan keterkaitan kuat diantara keduanya sehingga perlu dijelaskan.

Otak adalah organ tubuh manusia yang posisinya ditempatkan Tuhan secara terhormat di bagian atas tubuh manusia dan terlindungi dengan kokoh di bagian dalam tengkorak (batok) kepala. Posisi otak ini merupakan simbol yang menunjukkan bahwa manusia lebih mulia terhadap makhluk ciptaan Tuhan lainnya, misalnya hewan yang lokasi dan posisi otaknya sejajar dengan bagian tubuh terhina dan tempat meyimpan dan mengeluarkan kotorannya (perut dan dubur atau tumbuhan yang tidak mempunyai otak dan tidak diketahui dimana posisi otaknya jika ada. Dengan meng-otak atik kata OTAK, kata OTAK juga bisa merupakan kependekan kata (singkatan) dari kalimat: Organ Tubuh terpenting yang Ada di Kepala manusia.

Muhammad Izuddin Taufiq (2006) dalam bukunya Dalil Anfus Al Qur an dan Embriologi (Ayat-ayat tentang Penciptaan Manusia) mengatakan: "Bagian tubuh yang paling ambigu yang masih menyelimuti tubuh manusia adalah OTAK karena ia merupakan tempat berfikir yang berkaitan dengan roh atau jiwa, sedangkan roh atau jiwa itu merupakan sesuatu yang ambigu." (Taufik, 2006, p. 209). 
Maka tidak heran, jika ada yang menyamakan makna antara otak dan akal, begitu juga yang membedakannya. Harun Nasution termasuk orang yang membedakan, dan menyatakan bahwa akal dalam pengertian Islam bukanlah otak, melainkan daya berfikir yang terdapat dalam jiwa manusia; daya sebagaimana digambarkan Al Qur an, memperoleh pengetahuan dengan memperhatikan alam sekitarnya (Yahya, 1986, p. $13)$.

Otak adalah organ tubuh yang bukan hanya manusia, binatangpun memilikinya. Ketika otak bekerja dan salah satu kerja otak itu adalah berpikir, maka otak yang bekerja atau berfungsi tersebut disebut akal. Orang yang tidak berotak adalah orang yang tidak menggunakan otaknya berfungsi atau berpikir. Ayat yang berkaitan dengan otak adalah ubun-ubun yang pada surat al-Alaq ayat 15-16 :

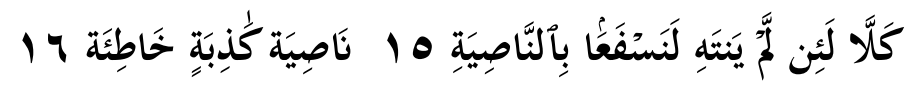

Ketahuilah, sungguh jika dia tidak berhenti (berbuat demikian) niscaya Kami tarik ubun-ubunnya. (yaitu) ubun-ubun orang yang mendustakan lagi durhaka. (Q.S. Al-Alaq : 15-16).

Otak yang berfungsi dan disebut akal inilah yang membedakan manusia dengan binatang melata, dan manusia dengan manusia, - al-insān hayawān al-nātịq, manusia adalah hewan yang berpikir, man as the animal that reasons - sebagaimana juga terpapar secara tersirat dan tersurat sejak 14 abad yang lampau di dalam QS. al-Anfal [8]: 22, dimana Allah SWT. berfirman :

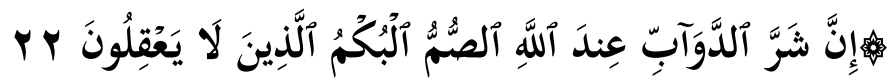

"Sesungguhnya binatang (makhluk) yang seburuk-buruknya pada sisi Allah ialah; orang-orang yang pekak dan tuli yang tidak mengerti apa-apapun".

Menurut Allah SWT kelebihan manusia dengan binatang, tumbuhan dan manusia lainnya adalah terletak pada berfungsi atau tidaknya otak untuk berpikir. Ibnu Sina (980-1037), filosof muslim yang terkenal di timur dan di barat menyatakan bahwa manusia mempunyai tujuh kemampuan, yaitu: 1) makan, 2) tumbuh, 3) berkembang biak, 4) pengamatan hal-hal yang istimewa, 5) pergerakan di bawah kekuasaan, 6) ketahuan (mengetahui) dari hal-hal yang umum, 7) memiliki kehendak memilih yang bebas. Tumbuh-tumbuhan hanya memiliki kemampuan 1, 2 dan 3, sedangkan hewan memiliki kemampuan 1, 2, 3, 4, dan 5. Kemampuan 6 dan 7 inilah yang sangat potensial membudidayakan otak untuk berfikir yang tidak dimiliki oleh makhluk ciptaan Allah lainnya dan membedakannya, bahkan juga membedakan antar sesama manusia ketika manusia tidak mau mempergunakan otaknya untuk berfikir seperti yang dijelaskan Allah SWT. dalam firman-Nya tersebut di atas. Bahkan Allah SWT. menjelaskan bahwa kedudukan manusia yang tidak mau mempergunakan otaknya untuk 
berpikir lebih rendah/hina dari binatang ternak sebagaimana disebutkan dalam QS. Al A raaf [7]: 179 ;

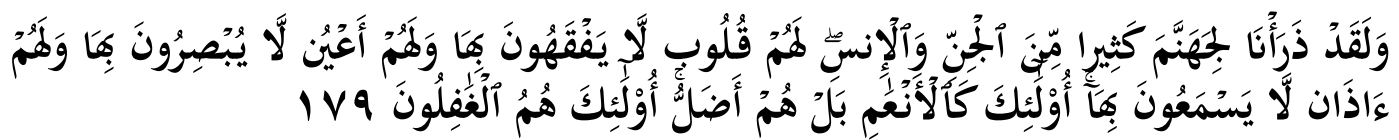

"Dan sesungguhnya Kami jadikan untuk (isi neraka Jahannam) kebanyakan dari jin dan manusia, mereka mempunyai hati, tetapi tidak dipergunakannya untuk memahami (ayat-ayat Allah) dan mereka mempunyai mata (tetapi) tidak dipergunakannya untuk melihat (tanda-tanda kekuasaan Allah), dan mereka mempunyai telinga (tetapi) tidak dipergunakannya untuk mendengar (ayat-ayat Allah). Mereka itu sebagai binatang ternak, bahkan mereka lebih sesat lagi. Mereka itulah orang-orang yang lalai".

Ibnu Khaldun (1332-1406), cendekiawan muslim yang sangat ahli dalam ilmu sejarah, sosiologi dan politik adalah sosiolog muslim pertama yang sangat terkenal dan fenomenal dengan karyanya Muqaddimah, mengatakan: bahwa Allah membedakan manusia dan lain-lain hewan dengan kesanggupan berpikir, sumber dari segala kesempurnaan, dan puncak dari segala kemuliaan dan ketinggian di atas lain-lain makhluk. Sebabnya ialah karena pengertian, yaitu kesadaran dalam diri tentang yang terjadi di luar dirinya, hanyalah ada pada hewan saja, tidak terdapat pada lain-lain barang (yang makhluk). Sebab hewan menyadari akan apa yang ada di luar darinya dengan perantaraan panca indra (pendengaran, penglihatan, pembauan, perasaan lidah dan penyentuhan) yang diberikan Allah kepadanya.

Sekarang manusia memahami ini dengan kekuatan memahami apa yang ada di luar dirinya dengan perantaraan pikirannya yang ada di balik panca indranya. Pikiran bekerja dengan perantaraan kekuatan yang ada di tengah-tengah otak yang memberi kesanggupan kepadanya menangkap bayangan benda-benda yang biasa diterima oleh panca indra, dan mengembalikan benda-benda itu dalam ingatannya sambil meringkasnya lagi bayangan-bayangan lain dari bayangan benda-benda itu. Refleksi terdiri dari penjamahan bayangan-bayangan ini (dibalik perasaan) oleh akal, yang memecah atau menghimpun bayangan-bayangan itu (untuk membentuk bayanganbayangan lain).

Menurut Imam Al Ghazali (1058-1111) (Nasution, 1988, p. 205), seorang pemikir besar Islam, dengan mengacu pada pengertian kerja atau fungsi akal menyatakan bahwa akal itu tidak bertempat, baik di dalam maupun di luar badan manusia, bersifat immaterial, dan tidak terbagi bagi. Akal berhubungan dengan badan dalam bentuk: (1) muqbil ala al-badan (menghadap badan), mufid lahu (memberi keuntungan), dan (3) mufid alaih (mengalir kepadanya). Tiga bentuk ini menitik beratkan pada fungsi, proses atau kegiatan.

Akal sebagai organ yang mengikat dan menahan secara filosofis juga dijelaskan oleh pemikir Islam dari Malaysia, Syed Muhammd Naquib Al Attas, adalah sesuatu 
organ aktif dan sadar. Ini menunjukkan pada fakta yang sama dan bermakna sama dari apa yang ditunjuk oleh kata: qalb, rūh, dan nafs. Sebagaimana Al Ghazali, Al-Attas berpendapat bahwa keempat kata itu bermakna sama. Kesemuanya menunjukkan realitas yang bertingkat-tingkat (marātib al-wujūd).(Pasiak, 2004, p. 194).

Pada masa pra-Islam, akal hanya berarti kecerdasan praktis yang ditunjukan seseorang dalam situasi yang berubah-ubah. Akal, menurut pengertian pra-Islam itu, berhubungan dengan pemecahan masalah. Karena itu, ia bersifat praktis saja. Akal seperti itu, menurut istilah psikologi kogntif, adalah problem solving capacity (kemampuan untuk memecahkan masalah dan menemukan jalan keluar dalam situasi apa pun juga) (Pasiak, 2004, p. 197).

Seorang penyair-perampok pra-Islam, Al-Shanfara, sebagaimana dikutip oleh Toshihiko Izutsu (Izutsu, 1997, p. 65), telah memakai kata itu - dengan makna praktisnya - dalam syairnya: Selama seseorang menggunakan kecerdasannya (wa huwa ya'qilu) maka tidak akan tarjadi peristiwa yang memalukan ketika ia tidak tahu apa yang harus dilakukan, entah ketika ia berada di jalan yang akan ia tuju, atau tergesa melepaskan diri dari sesuatu yang dibencinya.

Dengan contoh syair itu, tampak bahwa kata aql sudah sangat tua. Ia termasuk kata tradisional pra-Islam yang dipinjam Islam melalui Al-Quran. Kata-kata itu merupakan kata yang biasa dipakai oleh masyarakat Arab pra-Islam.

Izutsu mengkaitkan akal dengan kecerdasan, maka akal adalah kecerdasan praktis atau mengikat dan menahan adalah makna dasar kata itu sebagaimana ia dipakai oleh orang Arab pra-Islam. Ia lebih cocok atau lebih dekat dengan kegiatan penalaran logis, sebuah cara berpikir yang mengandalkan fakta dan langkah-langkah rasional. Untuk makna ini, kata aql lebih mungkin disebut reason (Inggris), rasio (Latin), verstand (Jerman), dan Dianoia (Yunani). Dari prosedur kerjanya, kata ini cocok untuk menyebut cara kerja dari otak kiri yang berpikir secara vertical (Pasiak, 2004, p. 190).

Baik Harun, Gozali, maupun Al-Attas membedakan dan memisahkan otak dan akal, bahkan cenderung menyiratkan bahwa pengertian akal itu kerja jiwa (qalb, rūh dan nafs), sedangkan Izutsu lebih menyiratkan bahwa secara historis pra-Islam akal itu kerja kognitif otak sebagaimana juga dinyatakan oleh Ibnu Khaldun bahwa akal itu kerja otak baik kognitif maupun imajinatif dan dengan jelas tersirat dan tersurat pada Al Quran Surah Al-Anfal \{8\}: 22 dan Surah Al-A'raf [9]: 179.

Dengan demikian bahwa akal itu adalah fungsi otak yang jika bekerja akan berpikir atau salah satu kerja otak adalah berpikir. Allah SWT dalam Surah Al Anfal [8]: 22 tidak menggunakan kalimat yang tidak menggunakan otaknya, adalah hikmah tersembunyi untuk memotivasi manusia agar memperhatikan dirinya, menggunakan otaknya untuk meneliti (men-tafakuri dan men-tadabburi) tentang organ otak. Juga 
untuk memahami bagaimana bekerjanya dan berfungsinya otak manusia; apakah otak sama dengan akal, bagaimana kaitan otak dengan akal, jiwa (qalb), rūh dan nafs serta bagaimana memaksimalkan otak berpikir manusia untuk mentafakkuri dan mentadabburi ayat-ayat Allah baik yang tertulis dalam al-Quran maupun yang tidak tertulis di seantero jagat alam semesta ini, menjadi obyek penelitian, pengamatan dan penjelajahan otak manusia. Allah SWT. telah memotivasi manusia sejak 14 abad yang lampau melalui lisan nabi Muhammad SAW sebagaimana dijelaskan dalam al-Quran Surat Ali-Imran ayat 190-195 :

Akal dan pikiran adalah produk organ otak. Kadangkala orang mengatakan akal pikiran, karena otak yang berpikir pertanda otaknya berfungsi dan menunjukkan eksistensi akal atau pikiran, sebagaimana pernah dikatakan Plato bahwa bepikir itu berpusat di kepala, begitu juga dengan Rene Descartes yang mengatakan bahwa pusat jiwa ada di kelenjar pineal otak, maka cogito ergo sum (aku berpikir, sebab itu aku ada). Sedangkan Michael Persinger dan Vilyanur Ramachandran, ahli bedah otak dari Amerika pada dekade akhir abad 20 ini dalam penelitiannya tentang otak menyimpulkan ada fenomena God Spot dalam lobus temporalis otak (sekitar pelipis).

Pada dekade otak (1990-2000), dimana penemuan Moleculer Biology of Cognition $(M B C)$, telah mampu mencitrakan kemampuan otak organ ciptaan Tuhan melampaui apa yang diketahui selama ini, termasuk apa yang sebelumnya diketahui oleh Ibn Sina dan Ibn Rusyd, yang menjelaskan daya-daya berfikir manusia dan Ibnu Khaldun yang menjelaskan peran otak dalam proses berpikir serta Rene Descartes yang berkata tentang Cogito (pikiran) manusia. Penemuan MBC tersebut memperlihatkan bahwa halhal kejiwaan manusia seperti berpikir, merasa, emosi, ingatan, persepsi, yang dahulu menjadi lahan mutlak para filosof dan psikolog dan karena itu sangat spekulatif kini dapat ditelaah secara lebih lugas dan jelas. Begitu juga penemuan tentang neurotransmiter, amigdala, dan sistem limbik pada otak memberikan pengetahuan mengenai apa yang disebut akal itu.

Tentang hubungan otak dan jiwa, beberapa puluh tahun lalu, ahli otak John Eccles dalam bukunya, The Understanding of the Brain (1973:193), mengatakan, bahwa secara teoritis ia menggunakan konsep 3 dunia dari Karl Popper untuk menjelaskan hubungan otak dan jiwa manusia.

Neurosaintis Erick Kandel, yang memperoleh Nobel Kedokteran, membuktikan hubungan otak dan jiwa melalui risetnya soal memori siput Apylasia californica. Ia berhasil membuktikan secara molekuler, kejadian pada sel-sel saraf untuk menguatkan teori psikologi mazhab Behaviourisme, terutama penemuan Ian Pavlov. Pavlov terkenal dengan Classical Conditioning yang menyatakan bahwa respons makhluk hidup (ketika meneliti, ia menggunakan hewan percobaan berupa anjing) dapat dikondisikan melalui 
pengkondisian stimulus. Penemuan Pavlov yang semula masuk ke wilayah psikologi kini masuk wilayah molekuler. Perilaku anjing (kondisi psikologi) terjadi karena adanya pelepasan molekul saraf di ujung sel-sel saraf (kondisi neurobiologi).(Pasiak, 2006, p. 21)

Otak manusia secara jasmani/fisik tidak lebih besar dari seuntai anggur Australia, jauh lebih kecil dari sebuah kol sayur yang tergeletak di pasar tradisional, memiliki berat kurang dari $1,5 \mathrm{~kg}$., namun kemampuannya berjuta kali lebih hebat dari komputer manapun yang ada dan terhebat di dunia. Otak manusia bekerja mirip seperti CPU (Central Processing Unit) dalam sistem komputer.

Jika seekor lalat buah memiliki 100.000 sel aktif, seekor tikus memiliki 5 juta sel aktif, seekor kera 10 miliar sel aktif, maka manusia memiliki sekitar 100 miliar sel aktif sejak lahir. Dan sejak hari pertama kehidupan sel-sel tersebut membentuk koneksi belajar (atau sinapsis) dengan kecepatan luar biasa; 3 miliar perdetik.(Dryden \& Vos, 2000, p. 113)

\section{Pengertian Akal}

Kata akal yang sudah menjadi kata Indonesia, berasal dari kata arab al- 'aql dalam bentuk kata benda yang tidak terdapat dalam Al-Qur'an. Al-Qur'an hanya membawa bentuk kata kerjanya yaitu 'aqaluh dalam satu ayat, ta'qilūn 24 ayat, na'qil 1 ayat, ya'qiluha 1 ayat, dan ya'qilun 22 ayat. Kata-kata tersebut berarti faham atau mengerti. Seperti dalam surat Al-Baqarah, $2: 75$.

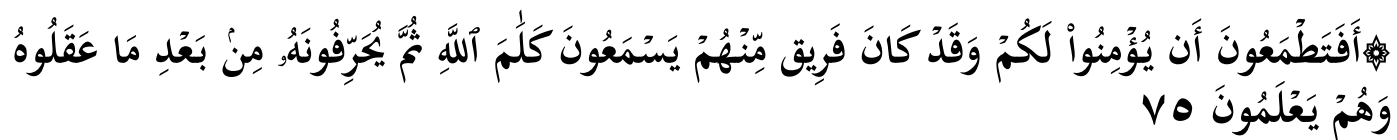

"Apakah kamu masih mengharapkan mereka akan percaya kepadamu, padahal segolongan dari mereka mendengar firman Allah, lalu mereka mengubahnya setelah mereka memahaminya, sedang mereka mengetahui?" (Q.S. Al-Baqarah: 75).

Dalam pemahaman Profesor Izutsu, kata 'aql di zaman jahiliyah dipakai dalam arti kecerdasan praktis (practical intelligence) yang dalam istilah psikologi modern disebut kecakapan memecahkan masalah (problem solving capacity). Orang berakal menurut pendapatnya adalah orang yang mempunyai kecakapan untuk menyelesaikan masalah setiap kali dihadapkan dengan problema apapun.

Kata 'aqala mengandung arti mengerti, memahami dan berfikir. Tetapi timbul pertanyaan apakah pengertian, pemahaman dan pemikiran dilakukan melalui akal yang berpusat dikepala? Dalam Al-Qur'an surat Al-Hajj ayat 46 dijelaskan bahwa pengertian, pemahaman dan pemikiran dilakukan melalui kalbu yang berpusat didada.(Yahya, 1986, pp. 5-7) 
Dalam buku tafsir Fì Dilālil Qur'an juga dijelaskan bahwa kata 'aql (akal) tidak ditemukan dalam Al-Qur'an, yang ada adalah bentuk kata kerja-masa kini, dan lampau. Kata tersebut dari segi bahasa pada mulanya berarti tali pengikat, penghalang. AlQur'an tidak menjelaskannya secara eksplisit, namun dari konteks ayat-ayat yang menggunakan akar kata 'aql dapat dipahami antara lain:

a) Daya untuk memahami dan menggambarkan sesuatu, seperti firman-Nya dalam QS Al-‘Ankabut (29): 43.

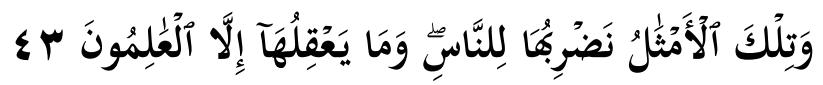

Dan perumpamaan-perumpamaan Ini kami buat untuk manusia; dan tiada yang memahaminya kecuali orang-orang yang berilmu.

Daya manusia dalam hal ini berbeda-beda. Ini diisyaratkan Al-Qur'an antara lain dalam ayat-ayat yang berbicara tentang kejadian langit-bumi, silih bergantinya malam dan siang, dan lain-lain. Ada yang dinyatakan sebagai bukti-bukti keesaan Allah Swt. bagi "orang-orang berakal” (QS Al-Baqarah (2): 164), dan ada juga bagi ulil albāb yang juga bermakna sama, tetapi mengandung pengertian lebih tajam dari sekedar memiliki pengetahuan.

Keanekaragaman akal dalam konteks menarik makna dan menyimpulkannya terlihat juga dari penggunaan istilah-istilah semacam nazara, tafakkur, tadabbur, dan sebagainya yang semuanya mengandung makna mengantar kepada pengertian dan kemampuan pemahaman.

b) Dorongan moral, seperti dalam firman-Nya QS. Al-'Anam(6): 151.

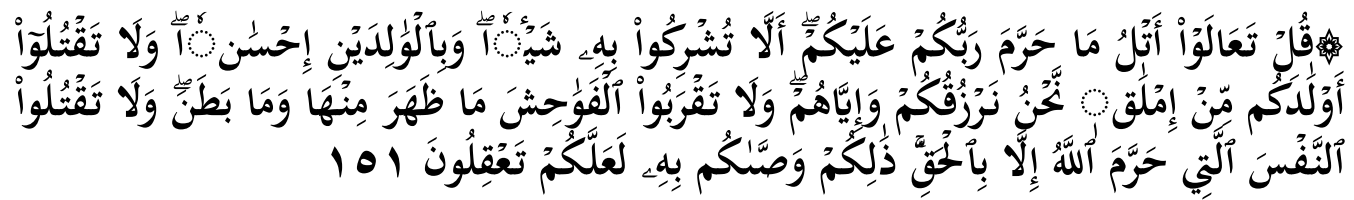

Katakanlah: "Marilah kubacakan apa yang diharamkan atas kamu oleh Tuhanmu yaitu: janganlah kamu mempersekutukan sesuatu dengan Dia, berbuat baiklah terhadap kedua orang ibu bapa, dan janganlah kamu membunuh anak-anak kamu karena takut kemiskinan, Kami akan memberi rezeki kepadamu dan kepada mereka, dan janganlah kamu mendekati perbuatan-perbuatan yang keji, baik yang nampak di antaranya maupun yang tersembunyi, dan janganlah kamu membunuh jiwa yang diharamkan Allah (membunuhnya) melainkan dengan sesuatu (sebab) yang benar". Demikian itu yang diperintahkan kepadamu supaya kamu memahami(nya).

c) Daya untuk mengambil kesimpulan dan pelajaran serta hikmah.(Quthb, 2001, p. 65)

Untuk maksud ini biasanya digunakan kata rusyd. Daya ini menggabungkan kedua daya diatas, sehingga ia mengandung daya memahami, daya menganalisis, dan menyimpulkan, sera dorongan moral yang disertai dengan kematangan berfikir. Seseorang yang memiliki dorongan moral boleh 
jadi tidak memiliki daya nalar yang kuat dan boleh jadi juga seseorang yang memiliki daya pikir yang kuat, tidak memiliki dorongan moral, tetapi seseorang yang memiliki rusyd, maka dia telah menggabungkan kedua keistimewaan tersebut. Dari sini dapat mengerti mengapa penghuni neraka dihari kemudian berkata dalam QS Al-Mulk (67): 10.

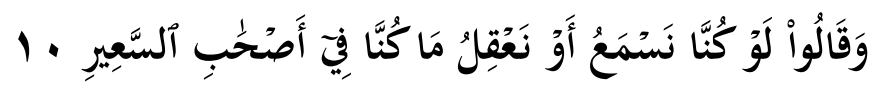

Dan mereka berkata: "Sekiranya kami mendengarkan atau memikirkan (peringatan itu) niscaya tidaklah kami termasuk penghuni-penghuni neraka yang menyala-nyala".

Dalam Kamus Besar Bahasa Indonesia disebutkan, akal adalah daya pikir untuk memahami sesuatu atau kemampuan melihat cara-cara memahami lingkungannya. Dalam eksiklopedi bahasa Arab, Lisān al-'Arāb, pakar bahasa Arab kenamaan, Sîbawayh, menjelaskan bahwa akal adalah sifat; 'uqila lahu syai'un berarti dijaga atau diikat (hubisa) akalnya dan dibatasi. U'tuqila lisānuhu iżā hubisa wa muni'a l-kalām (u'tuqila lidahnya, jika ia dibatasi dan dilarang berbicara), 'aqaltu al-ba''ir, berarti saya telah mengikat keempat kaki unta. Ibnu Bari mengartikan akal dalam syairnya sebagai sesuatu yang memberikan kesabaran dan wejangan (mau'izah) bagi orang yang mempunyai kebutuhan (hājah). Sehingga dikatakan: al-'āqil allaż̀̄ yahbisu nafsahu wa yarudduhu 'an hawāhā (orang berakal adalah yang mampu mengekang hawa nafsunya dan menolaknya). Maka, kata ma'qūl (masuk akal) berarti $m \bar{a}$ ta'qiluhu bi qalbika, yaitu sesuatu yang kamu nalar dengan hati/kalbumu.

Selanjutnya dijelaskan bahwa akal berarti kepastian (verification, making sure, certitude) dalam segala perkara. Menurut tinjauan Al Qur'an akal adalah Hujjah atau dengan kata lain merupakan anugerah Allah SWT. yang cukup hebat dengannya manusia dibedakan dari mahluk lain. Akal juga merupakan alat yang dapat menyampaikan kebenaran dan sekaligus sebagai pembukti dan pembeda antara yang haq dan yang bätil, serta apa yang ditemukannya dapat dipastikan kebenarannya, asal saja persyaratan-persyaratan fungsi kerjanya dijaga dan tidak diabaikan.

Untuk lebih jelasnya perhatikan dalil-dalil dari Al Qur'an sebagai bukti dari ucapan di atas :

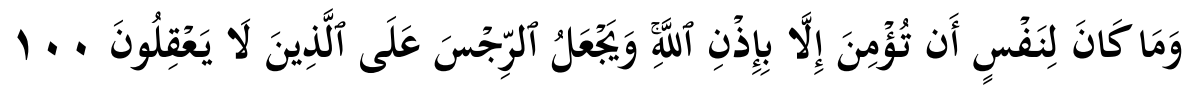

"Dan tiadalah sebarang Kuasa bagi seseorang untuk beriman melainkan Dengan izin Allah (melalui undang-undang dan peraturanNya); dan Allah menimpakan azab atas orang-orang Yang tidak mahu memahami (perintah-perintahNya)". (QS Yunus, $10: 100$ )

Dinamakan akal, karena dua alasan: pertama, mencegah pemiliknya (manusia) untuk terjerumus ke dalam jurang kehancuran, kedua, pembedaan yang membedakan 
manusia dari semua hewan. Makna kata akal yang berarti suatu yang terikat atau ikatan, juga diperkuat dengan hadits Abu Bakar ketika orang-orang Arab enggan membayar zakat. Beliau berkata: seandainya mereka enggan (membayar) kepadaku seutas tali ('iqālan) yang dulunya mereka bayarkan kepada Rasulullah $S A W$., sungguh akan aku perangi mereka. Kata 'iqāl yang berarti ikatan, benang atau tali, juga dikuatkan dengan hadits 'Adiy ibn Hâtim, dimana beliau berkata: "Ketika turun ayat (QS. al-Baqarah: 187) sehingga menjadi jelas bagimu antara 'benang putih' dan 'benang hitam', aku segera menyiapkan benang ('iqāl) hitam dan benang putih, lalu aku letakkan di bawah bantal. Kemudian aku melihatnya di malam hari, maka tidak jelas bagiku. Lalu aku pergi ke Rasulullah saw., aku pun menceritakan hal itu kepada beliau. Maka beliau pun bersabda: Sesungguhnya (ayat) itu (berarti) hitamnya malam dan terangnya siang".(al-Masri, 2005)

Redaksi "aqli" dalam al-Qur'an terulang sebanyak 49 kali, kecuali satu, semuanya datang dalam bentuk kata kerja seperti dalam bentuk ta'qilūn atau ya'qilūn. Kata kerja ta'qilūn terulang sebanyak 24 kali dan ya'qilūn sebanyak 22 kali, sedangkan kata kerja a'qala, na'qilu dan ya'qilu masing-masing satu kali (Qardawi, 1998: 19). Pengertian akal dapat dijumpai dalam penjelasan ibnu Taimiyah (2001: 18). Lafaf akal adalah lafal yang mujmāl (bermakna ganda) sebab lafal akal mencakup tentang cara berfikir yang benar dan mencakup pula tentang cara berfikir yang salah.

Adapun cara berfikir yang benar adalah cara berpikir yang mengikuti tuntunan yang telah ditetapkan dalam syara'. Lebih lanjut, Ibnu Taimiyah dalam bukunya yang berjudul Hukum Islam dalam Timbangan Akal dan Hikmah juga menyinggung mengenai kesesuaian naș al-Qur'an dengan akal, jika ada pemikiran yang bertentangan dengan akal maka akal tersebutlah yang salah karena mengikuti cara berpikir yang salah.

Allah SWT berfirman:

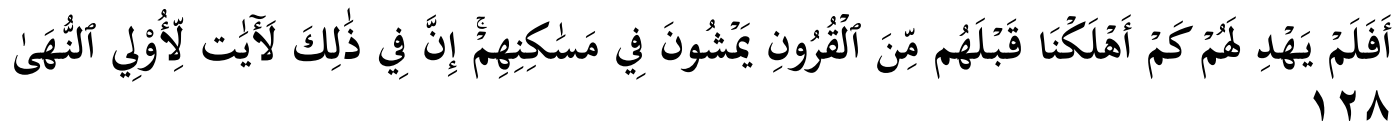

"Adakah tersembunyi serta belum jelas lagi kepada mereka: berapa banyak Kami telah binasakan dari kamu-kaum Yang terdahulu daripada mereka, sedang mereka sekarang berulang-alik melalui tempat-tempat tinggal kaum-kaum itu? Sesungguhnya pada Yang demikian ada tanda-tanda (untuk mengambil iktibar) bagi orang-orang Yang berakal fikiran". (Q.Ss Thahaa,20 : 128)

Abdurrahman As-Sa'di menjelaskan, ulun nuhā adalah orang-orang yang punya akal yang sehat lagi lurus dan memiliki jiwa tegar dan konsisten. Sebagaimana telah dipaparkan oleh Yusuf Al-Qaradhawi, sebenarnya pembicaraan akal dalam Al-Qur'an mencakup segala hal yang meliputi seluruh alam semesta, manusia dengan masa depan dan masa lalunya, serta ayat-ayat Allah ta'āla, baik yang tersirat maupun yang tersurat. 
Menurut Yusuf Al-Qaradhawi, siapa yang tidak menggunakan akalnya dalam berbagai masalah tersebut, berarti ia tidak berusahan mencari kebenaran, justru telah meniti jalan kesesatan.(Al-Qaradhawi, 1996, p. 21)

Sulaiman bin Shalih Al-Kharasyi menyatakan, melalui Al-Qur'an Allah telah mewajibkan kaum muslimin untuk menggunakan akal dan pikiran. Siapa saja yang sengaja meninggalkan akalnya, ia akan binasa dan berdosa.(Al-Khrasyi, n.d., p. 123) Allah Swt. berfirman:

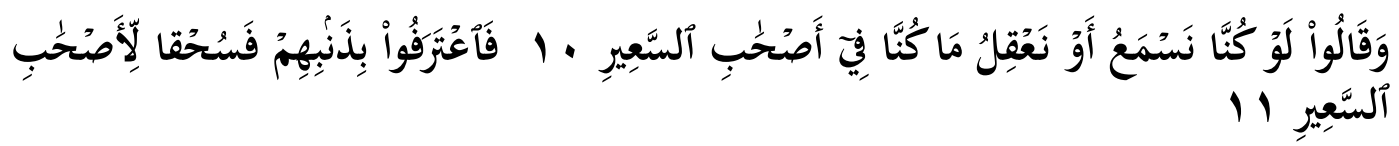

"Dan mereka berkata, 'Sekiranya (dahulu) kami mendengarkan atau memikirkan (peringatan itu) tentulah kami tidak termasuk penghuni neraka yang menyalanyala.' Maka mereka mengakui dosanya. Tetapi jauhlah (dari rahmat Allah) bagi penghuni neraka yang menyala-nyala itu." (Q.S. Al-Mulk: 10-11)

\section{KedUdUKan AKal Dalam Al-QUR'AN}

Telah dijelaskan bahwa penghargaan tertinggi terhadap akal terdapat dalam AlQur'an. Tidak sedikit ayat-ayat yang menganjurkan dan mendorong manusia supaya banyak berpikir dan mempergunakan akalnya.

Kata-kata yang dipakai dalam Al-Qur'an untuk menggambarkan perbuatan berpikir, bukan hanya 'aqala tapi juga ada banyak sinonimnya diantaranya :

1. Nazara, merenungkan dan perhatikan, terdapat dalam 30 ayat lebih, antara lain:

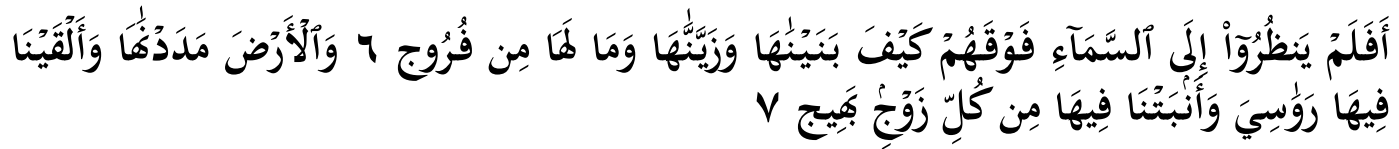

"Maka apakah mereka tidak memperhatikan akan langit yang ada di atas mereka, bagaimana kami meninggikannya dan menghiasinya dan langit itu tidak mempunyai retak-retak sedikitpun ?. Dan kami hamparkan bumi itu dan kami letakkan padanya gunung-gunung yang kokoh dan kami tumbuhkan padanya segala macam tanaman yang indah dipandang mata". (QS. Qaaf: 6-7)

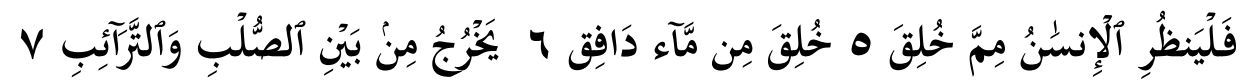

Maka hendaklah manusia memperhatikan dari apakah dia diciptakan? Dia diciptakan dari air yang dipancarkan, Yang keluar dari antara tulang sulbi laki-laki dan tulang dada perempuan. (QS. At-Thariq: 5-7)

2. Tadabbara, merenungkan terdapat beberapa ayat seperti:

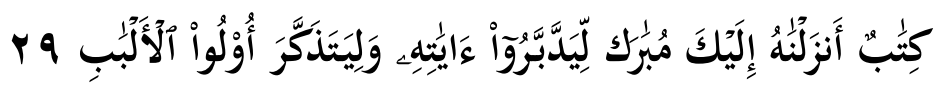

Ini adalah sebuah Kitab yang kami turunkan kepadamu penuh dengan berkah supaya mereka merenungkan ayat-ayatNya dan supaya mendapat pelajaran orangorang yang mempunyai fikiran. (QS. Shaad: 29)

3. Tafakkara, berfikir terkandung dalam 16 ayat, seperti: 


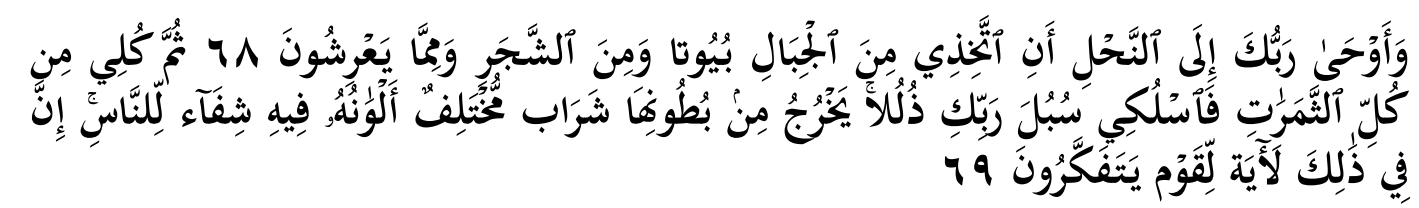

68. Dan Tuhanmu mewahyukan kepada lebah: "Buatlah sarang-sarang di bukitbukit, di pohon-pohon kayu, dan di tempat-tempat yang dibikin manusia". 69. kemudian makanlah dari tiap-tiap (macam) buah-buahan dan tempuhlah jalan Tuhanmu yang telah dimudahkan (bagimu). Dari perut lebah itu ke luar minuman (madu) yang bermacam-macam warnanya, di dalamnya terdapat obat yang menyembuhkan bagi manusia. Sesungguhnya pada yang demikian itu benar-benar terdapat tanda (kebesaran Tuhan) bagi orang-orang yang memikirkan. (QS. AnNahl: 68-69)

4. Faqiha, mengerti, faham terdapat dalam 16 ayat, seperti:

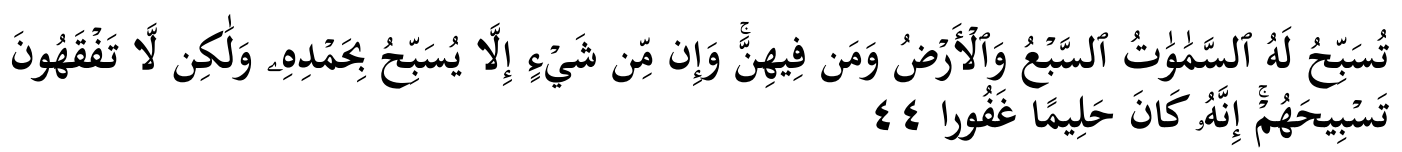

Langit yang tujuh, bumi dan semua yang ada di dalamnya bertasbih kepada Allah. dan tak ada suatupun melainkan bertasbih dengan memuji-Nya, tetapi kamu sekalian tidak mengerti tasbih mereka. Sesungguhnya dia adalah Maha Penyantun lagi Maha Pengampun. (QS. Al-Isra': 44)

5. Tażakkara, mengingat, memperoleh, peringatan, mendapat pelajaran, memperhatikan dan mempelajari, terdapat lebih dari 40 ayat, seperti:

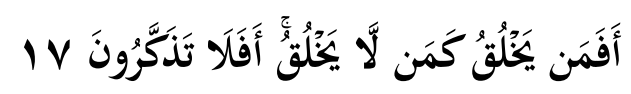

Maka apakah (Allah) yang menciptakan itu sama dengan yang tidak dapat menciptakan (apa-apa) ?. Maka Mengapa kamu tidak mengambil pelajaran. (QS.An-Nahl: 17)

Selain itu terdapat pula dalam Al-Qur'an sebutan-sebutan yang memberi sifat berfikir bagi seorang muslim, yaitu ulul albāb (orang berfikir), ulul 'ilm (orang berilmu), ulil abșār (orang yang mempunyai pandangan), dan ulin nuhā (orang bijaksana) (Yahya, 1986, pp. 39-42).

Semua bentuk ayat-ayat yang didalamnya terdapat kata-kata nazara, tadabbara, tafakkara, faqiha, fahima, 'aqala, serta ayat yang berisi sebutan ulul albāb, ulul 'ilm, ulil abșār, mengandung anjuran, dorongan dan perintah agar manusia banyak berfikir dan mempergunakan akalnya. Keduanya ini adalah ajaran yang jelas dan tegas dalam Al-Qur'an, sebagai sumber utama ajaran Islam.

Hadits sebagai sumber kedua dari ajaran Islam, juga memberi kedudukan tertinggi pada akal. Salah satu haditsnya sebagai berikut:

$$
\text { ا لد ين عقل لا د ين لمن لا عقل له }
$$

"Agama adalah penggunaan akal, tiada agama bagi orang yang tak berakal".

Akal terdiri atas unsur rasio dan hati/rasa. Setelah manusia memikirkan/merasio tanda-tanda kekuasaan Allah yang terbentang di alam atau tertulis dalam kitabNya maka 
tidak akan mengakui adanya Allah kalau hatinya tidak berfungsi, sebab buta, tidak yakin dan kotor (Hadhiri, 2005, p. 62).

Yang masuk akal belum tentu dapat dirasionalkan, sebab berfungsinya kemampuan rasio manusia sangat terbatas, hatinya buta dan menyebabkannya tidak yakin. Banyaknya manusia yang tidak mau memahami tanda-tanda kekuasaan dan keesaan Allah, mereka tidak mau menggunakan hati dan rasionya. Tapi ada juga yang mau menggunakan raiso namun mereka tidak yakin karena hatinya buta. Mereka bahkan lebih sesat daripada binatang yang tidak mempunyai akal (Hadhiri, 2005, pp. 62-63).

Pada masa-masa awal, saat Nabi Muhammad saw. masih hidup, pemahaman terhadap wahyu Allah bukan merupakan hal yang rumit. Sebab saat itu segala persoalan bisa ditanyakan langsung kepada Nabi yang nota bene mempunyai hak otortatif untuk menafsir wahyu-wahyu Allah. Namun setelah Nabi saw. wafat, permasalahan yang dihadapi umat Islam semakin kompleks. Oleh karena itu, masalah-masalah yang muncul namun belum ada tuntunan penyelesaiannya baik dalam al-Quran maupun as-Sunnah untuk mengatasinya maka muncullah jalan ketiga yakni Ijtihad.

Di sinilah peran akal, terutama dalam memahami wahyu Allah menjadi sangat urgen. Berkenaan dengan hal ini ada sebuah hadis yang sangat terkenal. Diceritakan pada pada saat Nabi Muhammad saw. hendak mengirim Mu'adz ke Yaman, Rasulullah bertanya: Dengan apakah engkau hendak menjalankan hukum? Mu'adz menjawab, "Dengan kitab Allah". Lalu Nabi bertanya lagi, "Bagaimana jika engkau tak mendapat keterangan dalam kitab Allah?" Mu'adz menjawab, "Dengan sunah Rasul." Nabi bertanya lagi,"Bagaimana jika dalam sunahku juga tak kau dapati?" Mu'adz menjawab,"Saya berijtihad dengan akal saya, dan saya tak pernah berputus asa."

Hadits ini sering dijadikan dalil berkenaan dengan peranan ijtihad dalam hukum Islam. Akal dalam deskripsi di atas menempati posisi yang signifikan dalam berijtihad. Namun demikian, di sana juga terlihat isyarat bahwa posisi akal secara hierarkis jatuh setelah al-Quran dan Sunah. Akal menempati posisi ketiga.

Berkenaan dengan akal, Nabi Muhammad saw. bersabda dalam sebuah hadis qudsinya : Demi kekuasaan dan keagunganku, tidaklah kuciptakan makhluk yang lebih mulia daripada engkau, kerna engkaulah aku mengambil dan memberi dan kerna engkaulah aku menurunkan pahala dan menjatuhkan hukuman.

Urgensi kehadiran akal juga dapat dilihat dalam hadis Nabi yang memerintahkan umat Islam untuk menuntut ilmu. Nabi saw. bersabda: 'Mencari ilmu wajib hukumnya bagi muslimin dan muslimat"(HR. Muslim). Perintah untuk mencari ilmu dapat dipahami bahwa manusia harus memaksimalkan potensi akalnya. Mengutip Syeikh azZarnuji dalam kitab Ta'lìm al-Mutaallim, ilmu inilah yang membedakan antara manusia dan makhluk lain. 
Ayat-ayat al-Qur'an yang secara khusus berbicara tentang akal, atau arti kata yang sepadan dengan redaksinya adalah diantaranya:

1. Yàqilün (Mempergunakan akal/orang-orang yang berakal), ada 16 ayat, yaitu:

a. 2 Ayat pada Surat Al Baqarah, 2 : Ayat 164, 171.

b. Al-Maidah, 5: ayat 58 .

c. Al Anfal, 8 : ayat 22.

d. 2 Ayat pada surat Yunus, 10 : ayat 42 dan 100.

e. Al Hajj, 22 : ayat 46.

f. Al Furqon, 25 : ayat 44.

g. Ash Shu ara, 26 : ayat 28.

h. 2 ayat pada surat Al Ankabut, 29 : ayat 35 dan 63.

i. 2 ayat pada surat Ar Rum,30 : ayat 24 dan 28.

j. Azzumar, 39 : ayat 43 .

k. Al Jashiyah, $45: 5$.

1. Al Hasyr, 59 : ayat 14.

2. Ulul Albāb (Orang-orang yang berakal), terdapat 13 ayat, yaitu:
a. 3 ayat pada surat Al Baqarah, 2 : Ayat 179, 197, 269.
b. 2 ayat pada surat Ali Imran, 3 : Ayat 7, dan 190 .
c. Al Maidah, $5:$ ayat 100.
d. Yusuf, 12 : ayat 111.
e. Ar Rad, 13 : ayat 19
f. Ibrahim, 14 : ayat 52.
g. 3 ayat pada surat Azzumar, 39 : ayat 9, 18 dan 21.
h. At Talaq, 65 : ayat 10.

3. Ulin Nuhā (Orang-orang yang berakal), ada ayat 2, yaitu : pada surat Thoha, 20 : ayat 54 dan 128.

4. Sufahā' (Kurang akal), ada 7 ayat, yaitu:
a. 2 ayat pada surat al Baqarah, 2 : ayat 142 dan 282.
b. An Nisa', 4 : ayat 5 .
c. 3 ayat pada surat Al A`raf, 7 : ayat 66,67 dan 155 .
d. Jin, 72 : ayat 4 .

5. Rosyīd (Berakal), ada 2 ayat pada surat Hud, 11 : ayat 78 dan 87.

6. Tufannidūn (=Sufahaa/kurang akal), ada ayat surat Yusuf, 12 : ayat 94.

7. Mirrah (Akal yang cerdas), ada pada ayat surat An Najm, 53 : ayat 6 .

8. Liż̄i Hijr ( yang memiliki ), ada pada ayat surat Al Fajr, 89 : ayat 5.

9. Qolbun au Alqoō Samaa' (orang-orang yang mempunyai akal atau yang menggunakan pendengarannya),ada pada ayat surat Qof, 50 : ayat 37. 


\section{Istawā (sempurna akalnya), ada pada ayat surat Al Qasas, 28 : ayat 14.}

Lawan dari akal adalah jahl, atau sering pula diistilahkan dengan hawa nafsu. Ditinjau dari keberadaan akal dan nafsu, mahluk-makhluk yang Allah karuniai kemampuan berpikir itu ada tiga jenis: malaikat, yang dikaruniai akal saja, tanpa nafsu; hewan, yang hanya dikaruniai nafsu, tanpa akal; dan manusia dan jin, yang Allah swt karuniai akal maupun nafsu.

Ayat-ayat Al Quran berikut dengan tegas memaksa untuk menyimpulkan bahwa hanya kaum Muslimin-Mu'mininlah yang menggunakan akalnya. Kaum yang lain, entah itu kafirin, musyrikin, munafikin, Nasrani, Yahudi, ataupun lainnya, oleh Al Quran dikatakan sebagai kaum yang tidak berakal (laa ya'qilun). Diantara ayat-ayat tersebut adalah :

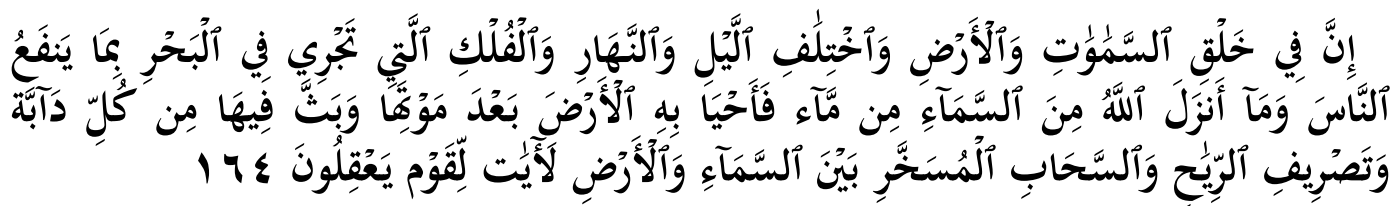

"Sesungguhnya pada kejadian langit dan bumi; dan pertukaran malam dan siang; dan (pada) kapal-kapal yang belayar di laut dengan membawa benda-benda yang bermanfaat kepada manusia; demikian juga (pada) air hujan yang Allah turunkan dari langit lalu Allah hidupkan dengannya tumbuh-tumbuhan di bumi sesudah matinya, serta Ia biakkan padanya dari berbagai-bagai jenis binatang; demikian juga (pada) peredaran angin dan awan yang tunduk (kepada kuasa Allah) terapung-apung di antara langit dengan bumi; sesungguhnya ada tanda-tanda (yang membuktikan keesaan Allah, kekuasaanNya, kebijaksanaanNya, dan keluasan rahmatNya) bagi kaum yang menggunakan akal fikiran (liqaumiy ya'qiluun)". (QS. Al Baqarah: 164)

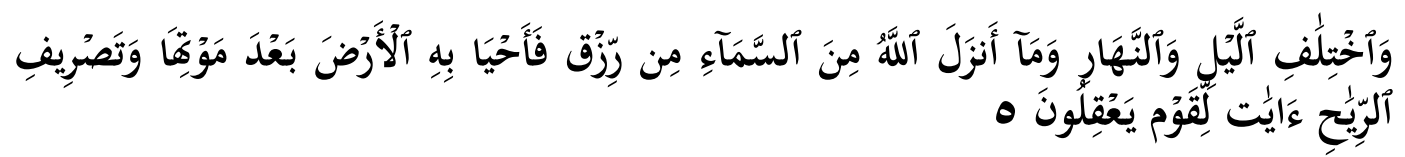

"Dan (pada) pertukaran malam dan siang silih berganti, dan juga (pada) rezeki yang diturunkan oleh Allah dari langit, lalu Ia hidupkan dengannya tumbuhtumbuhan di bumi sesudah matinya, serta (pada) peredaran angin, (semuanya itu mengandungi) tanda-tanda (yang membuktikan keesaan Allah, kekuasaanNya, kebijaksanaanNya, serta keluasan rahmatNya) bagi kaum yang mahu menggunakan akal fikiran" (liqaumiy ya'qiluun). (QS. Al Jatsiyah : 5)

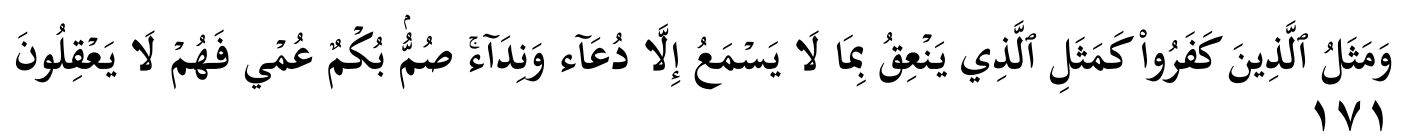

"Dan bandingan (orang-orang yang menyeru) orang-orang kafir, samalah seperti orang yang berteriak memanggil binatang yang tidak dapat memahami selain dari mendengar suara panggilan sahaja; mereka itu ialah orang-orang yang pekak, bisu dan buta; oleh sebab itu mereka tidak dapat menggunakan akalnya". (QS. Al Baqarah: 171) 


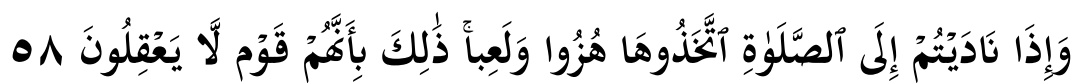

Dan apabila kamu menyeru untuk mengerjakan shalat, mereka menjadikannya (shalat itu) sebagai ejek-ejekan dan permainan. Yang demikian itu ialah karena mereka suatu kaum yang tidak berakal (laa ya'qiluun).(QS. Al Maidah: 58)

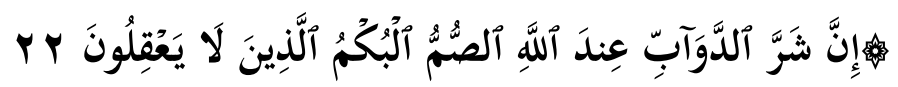

"Sesungguhnya sejelek-jelek makhluk yang melata di sisi Allah ialah orang-orang yang pekak lagi bisu, yang tidak mau menggunakan akal". (alladziina laa ya'qiluun). (QS. Al Anfal: 22)

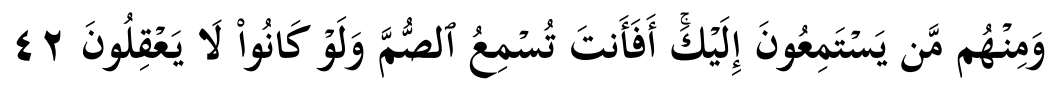

"Dan di antara mereka (yang ingkar) itu, ada yang datang mendengar ajaranmu; maka engkau (wahai Muhammad) tidak berkuasa menjadikan orang-orang yang pekak itu mendengar kalau mereka menjadi orang-orang yang tidak mau berakal". (laa ya'qiluun). (QS. Yunus: 42)

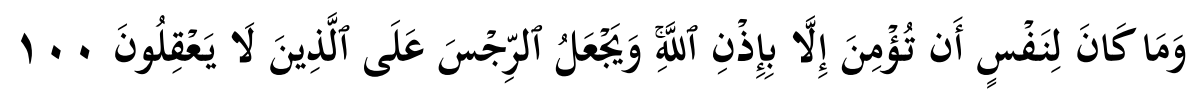

"Dan tiadalah sebarang kuasa bagi seseorang untuk beriman melainkan dengan izin Allah; dan Allah menimpakan azab (arrijsa) atas orang-orang yang tidak mau berakal". (laa ya'qiluun). (QS. Yunus: 100)

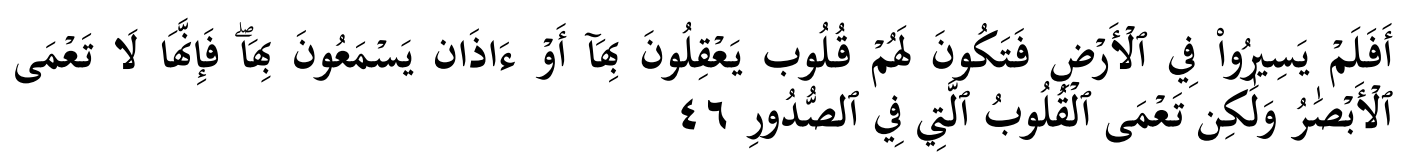

"Oleh itu, bukankah ada baiknya mereka mengembara di muka bumi supaya dengan melihat kesan-kesan yang tersebut - mereka menjadi orang-orang yang ada hati yang dengannya mereka dapat memahami (ya'qiluuna bihaa), atau ada telinga yang dengannya mereka dapat mendengar? (Tetapi kalaulah mereka mengembara pun tidak juga berguna) kerana keadaan yang sebenarnya bukanlah mata kepala yang buta, tetapi yang buta itu ialah mata hati yang ada di dalam dada”. (QS. Al Haj, 22: 46)

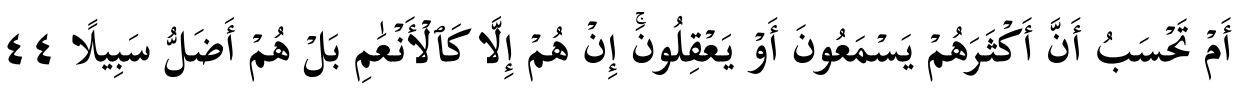

"Atau adakah engkau menyangka bahawa kebanyakan mereka mendengar atau memahami (ya'qiluun)? Mereka hanyalah seperti binatang ternak, bahkan mereka lebih sesat lagi”.'(QS. Al Furqan: 44)

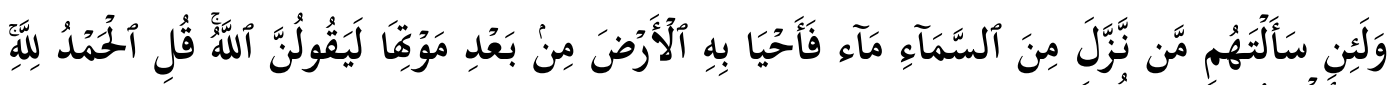

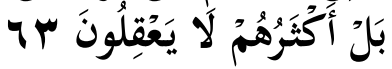

"Dan sesungguhnya jika engkau (wahai Muhammad) bertanya kepada mereka (yang musyrik) itu: "Siapakah yang menurunkan hujan dari langit, lalu Ia hidupkan dengannya tumbuh-tumbuhan di bumi sesudah matinya?" Sudah tentu 
mereka akan menjawab: "Allah". Ucapkanlah (wahai Muhammad): "Alhamdulillah", bahkan kebanyakan mereka tidak memahami". (Al Ankabut: 63)

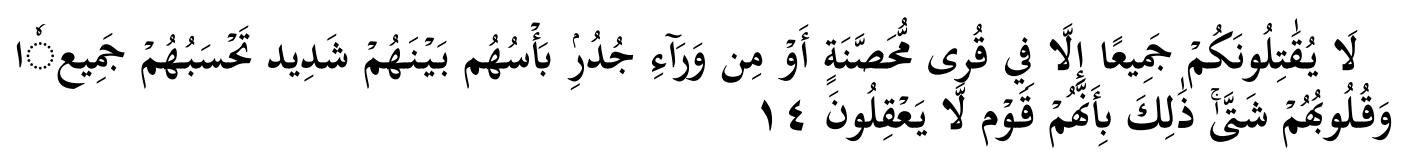

“(Orang-orang Yahudi dan orang-orang munafik) dengan keadaan bersatu padu sekalipun, tidak berani memerangi kamu melainkan di kampung-kampung yang berbenteng kukuh, atau dari sebalik tembok. (Sebabnya): permusuhan di antara mereka sesama sendiri amatlah keras; engkau menyangka mereka bersatu padu, sedang hati mereka berpecah belah. Yang demikian itu, kerana mereka adalah kaum yang tidak berakal”. (QS. Al Hasyr: 14)

Setelah jelas penegasan Al Quran bahwa hanya kaum mu'minin-muslimin sajalah yang menggunakan akalnya, sedangkan kaum lainnya adalah tidak berakal, maka tidak ada kesimpulan lain selain bahwa akal menduduki posisi sangat penting dalam beragama dan berkehidupan. Menggunakan akal, jika ingin selamat mencapai tujuan ukhrawi, jika menengok keadaan dunia saat ini, dimana science dan teknologi dikuasai oleh negara-negara maju yang kebanyakan adalah dunia Barat yang mayoritas penduduknya non-muslim -dan bahkan banyak penduduknya yang mengklaim atheis-, juga terlihat bahwa kehidupan sosial yang harmonis dan maju justru ditunjukkan oleh western ataupun non-muslim society itu, sementara kehidupan di banyak negara-negara muslim justru miskin, terbelakang dan semrawut, tentu ini menjadi ganjalan yang mengklaim muslimin ini. Bukankah majunya ilmu dan teknologi serta teraturnya society menunjukkan bahwa mereka adalah kaum yang berakal.

\section{E. Simpulan}

Manusia yang berakal merupakan makhluk Tuhan yang tertinggi dan akallah yang memperbedakan manusia dari binatang dan makhluk Tuhan yang lainnya. Karena akallah manusia bertanggung jawab atas perbuatan-perbuatannya dan akal yang ada dalam diri manusia itulah yang dipakai Tuhan sebagai pegangan dalam menentukan pemberian pahala atau hukuman kepada seseorang. Begitulah tingginya kedudukan akal dalam ajaran Islam, bukan hanya tinggi dalan soal-soal keduniaan saja tapi juga dalam soal keagamaan.

Penghargaan tertinggi terhadap akal ini sejalan pula dengan ajaran Islam lain yang erat hubungannya dengan akal, yaitu menuntut ilmu. Sesuai juga dengan wahyu pertama yang diterima oleh Nabi saw. Islam sangat mengapresiasi peran akal. Baik ayat alQur'an, Hadis, maupun kaidah ulama ushul fikih dan mufasir menekankan pentingnya peran akal sebagai instrument untuk memahami ajaran-ajaran Allah, maupun sebagai instrument pengembangan peradaban. Namun demikian, Islam menempatkan akal 
dengan batasan-batasan tertentu. Dihadapkan pada wahyu Allah, akal bersifat relative sedangkan wahyu Allah bersifat muthlak.

Menurut jumhur ulama (mufasir) ayat al-Qur'an terbagi setidaknya menjadi dua kelompok: ayat qaț'i yang bersifat gairu manqūlat al-ma'na dan ayat zanni yang bersifat manqūlat al-ma'na. Pada kelompok ayat jenis pertama akal manusia hanya bersifat tunduk, sedangkan pada kelompok ayat kedua, akal manusia diberikan keleluasaan untuk menafsir dengan ketentuan-ketentuan syara'. Otak dalam ayat neurosains dikenal dengan istilah ubun-ubun yang termaktub dalam Quran surat al-Alaq ayat $15-16$.

\section{F. Daftar Pustaka}

al-Masri, al-I. al-'Allîmah A. 1-F. J. al-dîn M. ibn M. ibn M. al-Ifrîqi. (2005). Lisân al'Arab. Dâr al-Sâdir.

Al-Khrasyi, S. bin S. (n.d.). Naqd Ushul 'Aqlaniyyin. Darul Úlum As-Sunnah.

Al-Qaradhawi, Y. (1996). Al- 'Aqlu wal Ilmu fil Qur'ān. Maktabah Wahbah.

Definition of NEUROSCIENCE. (n.d.). Retrieved November 29, 2019, from https://www.merriam-webster.com/dictionary/neuroscience

Dryden, G., \& Vos, J. (2000). Revolusi Cara Belajar. Kaifa.

European Brain and Behaviour Society. (2019). In Wikipedia. https://en.wikipedia.org/w/index.php?title=European_Brain_and_Behaviour_Societ y\&oldid=916758822

Hadhiri, C. (2005). Klasifikasi Kandungan Al-Qur 'ān Jilid 1. Gema Insani.

International Brain Research Organization. (2019). In Wikipedia. https://en.wikipedia.org/w/index.php?title=International_Brain_Research_Organiza tion\&oldid $=925768747$

Izutsu, T. (1997). Relasi Tuhan dan Manusia Pendekatan Semantik Terhadap Al Quran. Tiara Wacana.

Mental Health: A Report of the Surgeon General. (n.d.). 458.

Nasution, M. Y. (1988). Manusia Menurut Al-Ghazali. Rajawali Press.

Pasiak, T. (2004). Revolusi IQ/EQ/SQ Antara Neurosains dan Al Quran. PT Mizan Pustaka. 
Pasiak, T. (2006). Manajemen Kecerdasan. Mizan.

Quthb, S. (2001). Tafsir fi Zilalil Qur 'ān. Gema Insani.

Society for Neuroscience-About. (n.d.). Retrieved November 29, 2019, from https://www.sfn.org/about

Taufik, M. I. (2006). Dalil Anfus Al Qur an dan Embriologi. Tiga Serangkai.

Yahya, H. (1986). Akal dan Wahyu dalam Islam. UI Press. 